\title{
Geologic Reconnaissance and Test-well Drilling Cordova, Alaska
}

GEOLOGICAL SURVEY WATER-SUPPLY PAPER 1779-A

Prepared in cooperation with The Alaska Department of Health and Welfare and The Cordova Public Utilities

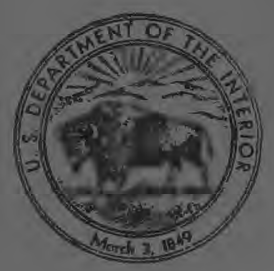




\section{Geologic Reconnaissance and}

\section{Test-well Drilling}

Cordova, Alaska

By KENNETH L. WALTERS

CONTRIBUTIONS TO THE HYDROLOGY OF THE UNITED STATES

GEOLOGICAL SURVEY WATER-SUPPLY PAPER 1779-A

Prepared in cooperation with the Alaska Department of Health and Welfare and the Cordova Public Utilities

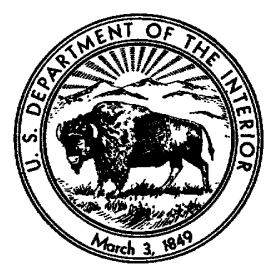


UNITED STATES DEPARTMENT OF THE INTERIOR

STEWART L. UDALL, Secretary

GEOLOGICAL SURVEY

Thomas B. Nolan, Director 


\section{CONTEN'TS}

\begin{tabular}{|c|c|}
\hline \multicolumn{2}{|r|}{ Page } \\
\hline & $A$ \\
\hline & \\
\hline Purpose and scope of the investigation & \\
\hline Location and general description of the area & 2 \\
\hline Description of the present water supply & \\
\hline Ing & \\
\hline ( & \\
\hline 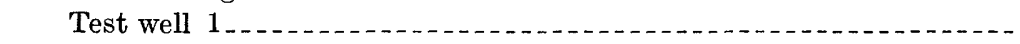 & \\
\hline - - - & J \\
\hline tests & \\
\hline 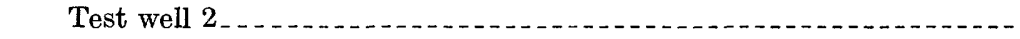 & 6 \\
\hline nt & \\
\hline $\mathrm{sts}_{\mathrm{t}}$ & \\
\hline ground water $\ldots \ldots$ & 8 \\
\hline 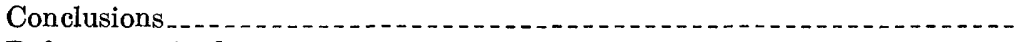 & 11 \\
\hline ces cited & 11 \\
\hline
\end{tabular}

\section{ILLUSTRATIONS}

Page

Plate 1. Geologic map of Cordova area, Alaska _............. In pocket

FIgURE 1. Index map of Alaska showing location of Cordova.

\section{TABLES}

TABLE 1. Log of test well 1

2. Log of test well 2

3. Chemical analyses of water at Cordova 



\title{
CONTRIBUTIONS TO THE HYDROLOGY OF THE UNITED STATES
}

\section{GEOLOGIC RECONNAISSANCE AND TEST-WELL DRILLING, GORDOVA, ALASKA}

\author{
By Kenneth L. Walters
}

\begin{abstract}
A study of the ground-water conditions at Cordova, Alaska, to determine the availability of supplies from previously unexplored ground-water sources was made in September and October 1961 by the U.S. Geological Survey, in cooperation with the Alaska Department of Health and Welfare and the Cordova Public Utilities.

During the investigation two test wells were drilled in a glaciated valley between Eyak Lake and Orca Inlet. One test well entered consolidated bedrock at a depth of about 120 feet, the other was drilled to a depth of 142 feet and penetrated only unconsolidated materials.

Test well 1 produced only a small amount of water when pumped; however, the low yield of this test well may have been due to improper screen-slot size rather than to the nature of the aquifer. Test well 2 was pumped at a rate of $130 \mathrm{gpm}$ (gallons per minute), with only a moderate amount of drawdown.

Water samples for chemical analyses were collected from both test wells and from Eyak Lake. The results of these analyses indicate that the ground water is of good chemical quality and there is little likelihood of sea water being drawn into wells after prolonged pumping. Attention should be given to the problem of chloride content of water from aquifers at depths greater than the depth of the deeper test well.
\end{abstract}

\section{INTRODUCTION}

\section{PURPOSE AND SCOPE OF THE INVESTIGATION}

An investigation of the ground-water conditions in the Cordova area was made during September and October 1961 by the U.S. Geological Survey, in cooperation with the Alaska Department of Health and Welfare and the Cordova Public Utilities. The investigation included reconnaissance geologic mapping and logging of two test wells. The purpose of the study was to obtain data that would help others determine the feasibility of developing unexplored groundwater sources.

During the course of the investigation, the principal emphasis was on test drilling and the testing of the water-yielding character of the materials penetrated. 
Test drilling was done with a cable-tool drill, owned by the Alaska State Department of Health and Welfare, and operated by employees of a well-drilling company who contracted to construct the wells. Test drilling and pumping were supervised by the author, under the general supervision of R. M. Waller, geologist in charge of the U.S. Geological Survey's ground-water investigations in Alaska.

\section{IOCATION AND GENERAL DESCRIPTION OF THE AREA}

The city of Cordova, about 145 miles east-southeast of Anchorage (fig. 1), at about lat $60^{\circ} 33^{\prime} \mathrm{N}$.; long $145^{\circ} 45^{\prime} \mathrm{W}$., lies on the southeast shore of Orca Inlet, which opens southward into the Gulf of Alaska. The city is in a low gap between the slopes of Mount Eyak to the north and Mount Eccles to the south. The lowland upon which the southern part of the city is built (pl. 1) separates Orca Inlet from Eyak Lake, which occupies a glacially scoured valley or former arm of Orca Inlet.

Cordova is accessible only by air or by boat, has a population of about 1,400 , and is primarily a base for commercial fishermen. It has two cold-storage plants and several canneries for the processing of salmon and crabs. The now abandoned Copper River and Northwestern Railroad formerly brought copper ore from the Kennecott mines to Cordova for shipment by water. The city is served by Pacific Northern Airlines, Cordova Airlines, and by oceangoing ships. Except for an area of about 4 square miles immediately surrounding the city, the land in the vicinity of Cordova is within the Chugach National Forest.

The mean annual temperature at Cordova is about $38^{\circ} \mathrm{F}$ and the mean monthly temperature is below freezing from November to March. The mean annual precipitation is about 95 inches.

\section{DESCRIPTION OF THE PRESENT WATER SUPPLY}

In 1961, at the time of this investigation, the Cordova water supply was obtained from several surface-water sources. The principal source of water is a creek which heads in the Heney Range, a few miles southeast of town. A rock and timber crib serves as a headworks to divert water from the creek into a 10 -inch wooden pipeline, which carries water by gravity across a hummocky muskeg area to Meals Lake. From Meals Lake, estimated to have a capacity of about 15 million gallons, water flows to the city through a wooden pipeline. A second reservoir near Meals Lake is also connected to the system; but because it is subject to contamination and is not suitable for regular use, it is held in reserve for fire protection. Water is also diverted from a stream at Merchison Falls, on the edge of Chugach National Forest, about a mile east of town, and flows by gravity into the city by wooden pipeline. A small reservoir on the hill overlooking 


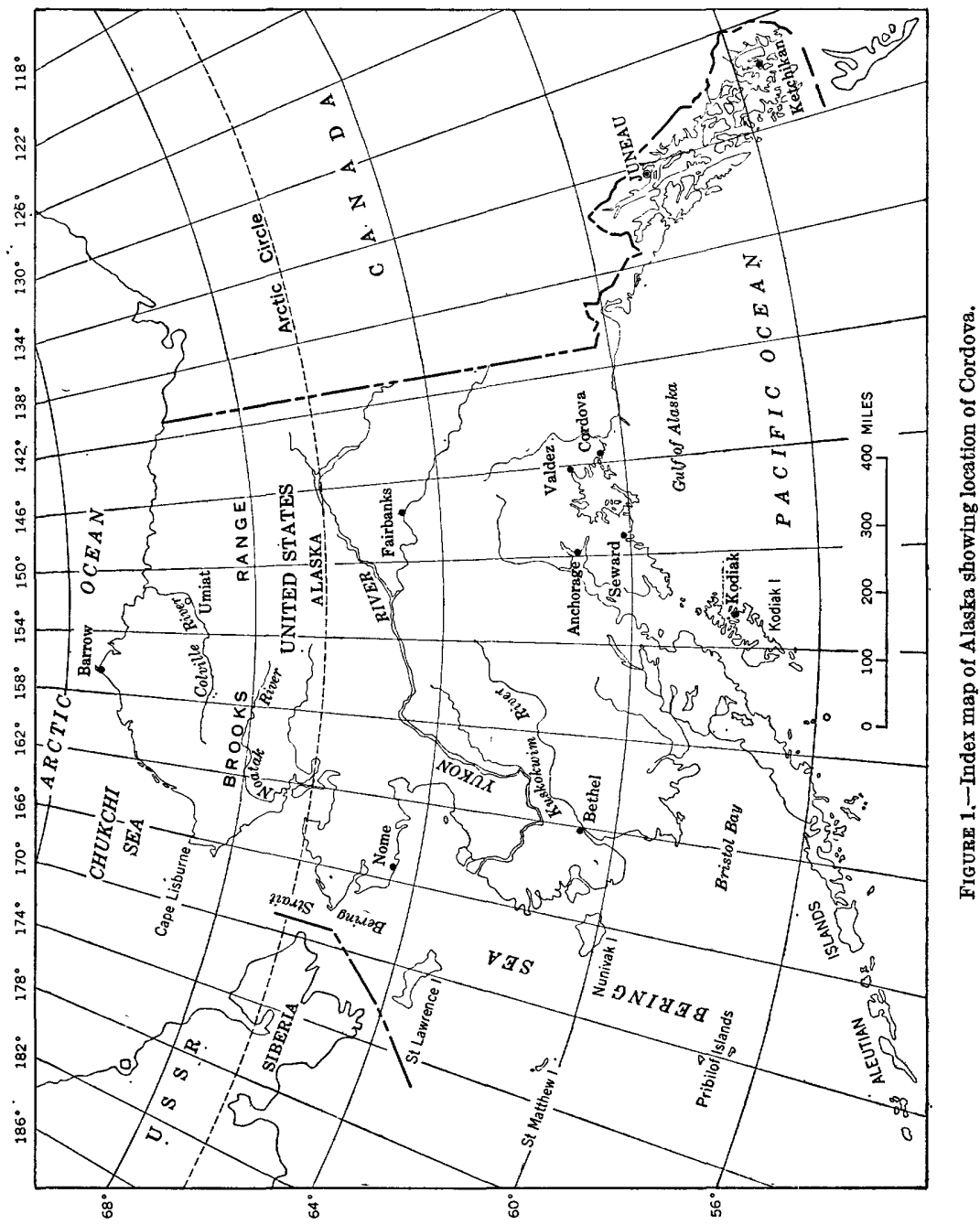


the northeast part of Cordova collects water to serve a small area nearby. When other sources are inadequate, usually during the winter months, water is pumped from Eyak Lake. Eyak Lake has been considered for a permanent source of supply, but reportedly is subject to pollution and would require treatment in addition to the chlorination that the supply from all sources now receives.

The Cordova water system is not metered; hence no accurate figures on usage are available. The city estimates that about 500,000 gallons per day are used from May to August when the canneries are operating. The consumption during the winter months probably is almost as high, because water taps are kept open to prevent freezing of the lines.

The inadequacy of the present system during the winter months when runoff is low, and the deterioration of the existing wooden pipelines led to this investigation of the possibilities of developing a ground-water supply. Cederstrom (1952, p. 16) had made a reconnaissance of Cordova in 1949 and indicated that an area near Eyak Lake appeared to be favorable for a shallow ground-water supply.

\section{GEOLOGIC SETTING}

A geologic reconnaissance of the area was made to help in the interpretation of drilling results. An attempt was made to learn about the subsurface geologic conditions from existing wells, but only a few very shallow wells were found.

The bedrock of the Cordova area is principally moderately to intensely deformed and fractured argillite and graywacke. The impermeable nature of the rock and the complete absence of springs indicate that the bedrock is not capable of yielding large supplies of water.

Eyak Lake occupies a glacially scoured valley, and the lowland between Orca Inlet and Eyak Lake is composed of glacial drift of a morainic nature. The glacial drift of the lowland, which is only a few feet above sea level, is composed principally of poorly stratified sand and clay and discontinuous lenses and pods of glacial till. Exposures of glacial till are more numerous at slightly higher altitudes along the edges of the valley (pl. 1). Banded or varved clay is exposed on both sides of the valley several feet above the general level of the lowland. The clay is of lacustrine origin and probably was deposited at a time when Orca Inlet was filled with glacial ice to an altitude considerably above sea level. At that time, the lower end of the valley now occupied by Eyak Lake must have been relatively free of ice. A few miles south of Cordova, thin and discontinuous glacial deposits mantle the surface at altitudes of several hundred feet above sea level. These deposits are too thin to be considered for the development of a ground-water supply. 


\section{TEST-WELL DRILLING}

It was decided early in the investigation that the most suitable area for test drilling was near the western end of Eyak Lake. Waterbearing sand and gravel of glaciofluvial origin, recharged from Eyak Lake, were thought to be present at shallow depth. The possibility of contamination by domestic sewage was at least no greater than in the area near Orca Inlet, and the possibility of sea-water encroachment would not be as great.

\section{TEST WELL 1}

\section{DESCRIPTION}

Test well 1 (pl. 1) was drilled near the northern margin of the lowland area, about 250 feet west of the northwest tip of Eyak Lake. It is 132 feet west and 63 feet south of the junction of Lake Avenue and the unnamed north-south street along the west end of Eyak Lake. A description of the material penetrated is given in table 1.

\section{PUMPING TESTS}

A cylinder pump was installed when the hole was at a depth of 89 feet and the unperforated casing was at a depth of 88 feet. Water entered the hole, therefore, through only the bottom foot. Pumping for 3 hours at a rate of about $60 \mathrm{gpm}$ (gallons per minute) resulted in a drawdown of 21.45 feet. Large quantities of sand were pumped with the water and it was decided to install a screen. The hole was

TABLE 1.-Log of test well 1

[Drilled Sept. 11-Oct. 11, 1961, by the Channel Drilling Co., Juneau, Alaska. Diameter, 6-inch]

\begin{tabular}{|c|c|c|}
\hline Material & $\begin{array}{c}\text { Thickness } \\
\text { (feet) }\end{array}$ & $\underset{\text { (feet) }}{\text { Depth }}$ \\
\hline 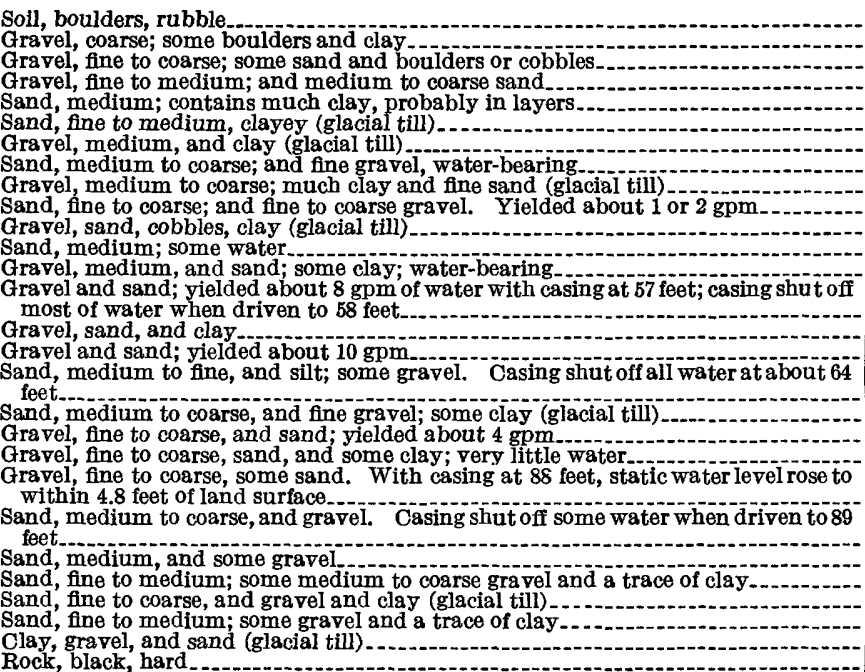 & $\begin{array}{r}2 \\
6 \\
6 \\
\mathbf{2} \\
10 \\
1 \\
\mathbf{5} \\
1 \\
5 \\
\mathbf{4} \\
\mathbf{6} \\
\mathbf{2} \\
5 \\
\mathbf{3} \\
\mathbf{3} \\
\mathbf{2} \\
\mathbf{1 1} \\
\mathbf{8} \\
\mathbf{1} \\
\mathbf{5} \\
\mathbf{1} \\
1 \\
\mathbf{1} \\
\mathbf{4} \\
16 \\
2 \\
\mathbf{4} \\
\mathbf{4} \\
\mathbf{4}\end{array}$ & $\begin{array}{r}2 \\
8 \\
14 \\
16 \\
26 \\
27 \\
32 \\
33 \\
38 \\
42 \\
48 \\
50 \\
55 \\
58 \\
61 \\
63 \\
74 \\
82 \\
83 \\
88 \\
89 \\
90 \\
94 \\
110 \\
112 \\
116 \\
120 \\
124\end{array}$ \\
\hline
\end{tabular}


drilled to a depth of 93 feet and a 5-foot 0.040-inch slot, wire-wrapped screen with a $2 \frac{1}{2}$-foot sump at the bottom was installed. The casing was then pulled back to $85 \frac{1}{2}$ feet. After installation of the screen (screened interval 851/2 to $90 \frac{1}{2}$ feet), 7 hours of surging removed 21 gallons of sand and silt. A turbine test pump was installed and a brief test was made.

After 2 hours of pumping at about $16 \mathrm{gpm}$, the water level was drawn down 29 feet below the static level of 4.60 feet below land surface. The pumping rate was increased to $23 \mathrm{gpm}$ and, after 2 additional hours, the water level declined to about 56 feet below land surface.

When the test well was pumped at a rate greater than $27 \mathrm{gpm}$, the water level was drawn down to 82 feet below land surface and the pump broke suction. When the screen was removed to permit deeper drilling, it was observed that the screen was badly plugged with sand, indicating that the screen-slot size was too small to obtain an accurate measure of yield and drawdown in the deposits tested.

\section{TEST WELL 2}

Test well 2 was drilled approximately midway between the north and south margins of the fill area (pl. 1), and about 200 feet west of the west end of Eyak Lake. During the summer of 1961 a well was dug at this site. The hole was abandoned at a depth of 59 feet because of inadequate yield. Test well 2 was drilled in the dug well, which is 480 feet south of test well 1 , across the road from the Dave Parmeter residence.

TABLE 2.-Log of test well 2

[Drilled October 12-30 by the Channel Drilling Co., Juneau, Alaska. Diameter 6 inches, cased from surface to $1341 / 2$ feet, 0.080 -inch slot wire-wrapped screen from $1341 \frac{1}{2}$ to $1391 \frac{1}{2}$ feet. Seal between screen and casing made by means of swaged lead packer. A 21/2-foot sump was placed below the screen. Log from 0 to 59 feet is from examination of partial sample suite of dug well]

\begin{tabular}{|c|c|c|}
\hline Material & $\begin{array}{c}\text { Thickness } \\
\text { (feet) }\end{array}$ & $\underset{\text { (feet) }}{\text { Depth }}$ \\
\hline $\begin{array}{l}\text { Clay, silty, tan brown } \\
\text { Sand, very fine to fine, and some coarse gravel } \\
\text { Gravel, fine to coarse, and much fine sand } \\
\text { Clay, very gravelly (glacial till) } \\
\text { Clay and gravel (glacial till) } \\
\text { "Hardpan"' reported to depth of } 59 \text { feet (bottom of dug well) } \\
\text { Clay, blue, and sand and gravel (glacial till) } \\
\text { Sand, fine to medium, and some gravel and clay. Enough water to drill } \\
\text { Sand, fine to medium; some gravel, very little clay } \\
\text { Sand, fine to medium, and medium gravel and clay } \\
\text { Sand, fine to medium, and clay. } \\
\text { Sand, fine to coarse, and medium gravel and some clay (boulder at } 85 \text { feet) } \\
\text { Sand, fine to coarse; some gravel and clay. Not enough water to drill } \\
\text { Gravel, fine to medium, and coarse sand; water rose to within } 8 \text { feet of land surfacee } \\
\text { Gravel, medium, and fine to medium sand; trace of clay } \\
\text { Gravel, medium, and coarse sand } \\
\text { Sand, fine to coarse, and some gravel } \\
\text { Gravel, fine to medium, and coarse sand } \\
\text { Sand, fine to coarse, and some gravel. } \\
\text { Sand, gravel, and clay (glacial till) } \\
\text { Sand, fine to coarse, and gravel... } \\
\text { Sand, fine; some gravel and clay balls } \\
\text { Sand, fine to coarse, and gravel-. }\end{array}$ & \begin{tabular}{r|r}
13 \\
11 \\
9 \\
2 \\
2 \\
22 \\
7 \\
3 \\
3 \\
8 \\
2 \\
5 \\
1 \\
15 \\
3 \\
10
\end{tabular} & $\begin{array}{r}13 \\
24 \\
33 \\
35 \\
37 \\
59 \\
66 \\
69 \\
77 \\
79 \\
84 \\
85 \\
100 \\
103 \\
113 \\
114 \\
121 \\
122 \\
128 \\
132 \\
135 \\
138 \\
142\end{array}$ \\
\hline
\end{tabular}




\section{DEVELOPMEN'T}

After the screen was installed, a surge block was attached to the drill stem, and the well was developed using the action of the drill. Surging was continued for several hours until sand no longer entered the well. A total of 50 gallons (about $6 \frac{1}{2} \mathrm{cu} \mathrm{ft}$ ) of fine- to mediumgrained sand was removed by surging before the test pump was installed.

\section{PUMPING TESTS}

A preliminary test was made on test well 2 to determine a practical pumping rate for the actual test. When pumped for about 5 hours at $75 \mathrm{gpm}$, the water level was drawn down 19.80 feet below the static level of 3.94 feet below land surface. The pumping rate was then increased to $108 \mathrm{gpm}$ for 1 hour and 25 minutes, which increased the drawdown to 25.58 feet. Pumping was continued at increasing rates until the drawdown reached about 33 feet; at this time pumping was stopped and the water level recovered 24.30 feet in 5 minutes.

Following the preliminary test, the well was not pumped for 2 days to allow the water level to recover to normal static level before test pumping was resumed. An attempt was then made to pump the test well at a continuous rate of $145 \mathrm{gpm}$; however, the gasoline engine used to operate the pump did not maintain a uniform speed, and the pumping rate decreased to about $130 \mathrm{gpm}$ after about 1 hour.

After 24 hours and 36 minutes of pumping at the rate of about 130 $\mathrm{gpm}$, the water level in test well 2 was drawn down 33.95 feet below the static water level of 4.05 feet below land surface. The pumping rate was then increased to $170 \mathrm{gpm}$ and, after 1 hour, the water level declined to 39.60 feet below static level. During the test, fluctuations in water level that could not be attributed to pumping were observed. These fluctuations, about 0.5 foot in magnitude, probably were caused by tidal effects. When pumping was stopped, the water level recovered to within 9.31 feet of static level in 19 minutes.

The water level in test well 1 was drawn down 10.72 feet after pumping test well 2 for 24 hours and 28 minutes at the rate of about $130 \mathrm{gpm}$.

Determinations of the coefficients of transmissibility and storage were made by means of the Theis nonequilibrium method, and also by the modified nonequilibrium formula. The coefficient of transmissibility may be defined as the number of gallons of water a day, at the prevailing temperature, that is transmitted through each mile width of the aquifer under a hydraulic gradient of 1 foot per mile. The coefficient of transmissibility usually is expressed in gallons per day per foot. The coefficient of storage of an aquifer is the volume of water it releases from or takes into storage, per unit surface area of the aquifer per unit change in the component of head normal to that 
surface. The storage coefficient is a ratio of volumes, and is dimensionless.

A value of about 7,000 gallons per day per foot was obtained for the coefficient of transmissibility. The coefficient of storage was determined to be about $3.5 \times 10^{-5}$. Such a low value for the coefficient of transmissibility indicates that test well 2 does not tap a prolific aquifer. However, only a 5 -foot length of screen was installed in the well, and the slot size of the screen was not selected on the basis of the particle size of the materials penetrated. It is possible that part of the drawdown in test well 2 was due to partial plugging of the screen and was somewhat greater than the drawdown in the aquifer on the outside of the screen. The appreciable drawdown in test well 1 , caused by pumping of test well 2 , suggests, however, that the screen loss in test well 2 probably was not great.

If test well 2 were pumped continuously for 150 days at the rate of $350 \mathrm{gpm}$ with no recharge, the water level would be drawn down almost to the top of the screen. The resulting drawdown in test well 1 would be about 60 feet. However, the cone of influence of test well 2 would extend under Eyak Lake after a short period of pumping and some recharge to the ground-water reservoir would be induced long before the above conditions were met. The amount that the groundwater reservoir would be recharged by infiltration from Eyak Lake would depend upon the permeability of the materials underlying the lake bottom. The water level in test well 2 recovers very rapidly when pumping is discontinued, and a new drawdown cycle could be started after a brief interruption of pumpage.

\section{CHEMICAL QUALITY OF GROUND WATER}

The lowland upon which the test wells are located is only a few feet above sea level, and water from deep wells could conceivably be too salty for municipal use. Because the iron content of the existing supply is somewhat objectionable and because of concern over the possible chloride content of ground water in the area, samples of water for chemical analysis were collected during drilling.

Samples were collected from test well 1 at depths of 93 and 124 feet. Chemical analyses of these samples (Nos. 1 and 2, table 3) indicate that there is no appreciable change in quality of water with increased depth of the well. Samples were collected from test well 2 after about 5 hours of pumping at $75 \mathrm{gpm}$ (No. 3, table 3) and after about 24 hours of pumping at approximately $130 \mathrm{gpm}$. Sample 3 differs considerably from the two samples from test well 1 . This difference may be due more to the effects of the higher pumping rates for test well 2 than to the difference in depth of the two wells. The increased 
chloride and sodium contents of sample 3 suggest that salt water may be in the deposits. However, the concentration of chloride in all samples was so small, 3 to $42 \mathrm{ppm}$ (parts per million), that there is no reason for concern. According to the U.S. Public Health Service (1962), the chloride content of drinking water should not exceed 250 ppm.

Sample 4 was taken and analyzed for only selected chemical constituents to determine whether any chemical changes occurred after extended pumping. The chloride content of sample 4 was $42 \mathrm{ppm}$ or $13 \mathrm{ppm}$ greater than that of sample 3 . The slight increase in hardness of sample 4 over that of sample 3 may be due to a slightly smaller concentration of sodium in sample 4 .

Because of the slight increase in chloride content of sample 4 over sample 3, a prolonged period of pumping and sampling of test well 2 was started by the city of Cordova on February 19, 1962. Pumping was at the rate of about $125 \mathrm{gpm}$. The first sample collected (No.5, table 3) had the same chloride content and specific conductance as the first sample collected during the earlier test (No. 3). Sample 6, collected after two days of pumping, has practically the same chloride content and specific conductance as sample 4 , which was collected after 24 hours of pumping in the earlier test.

The chloride content and specific conductance did not change materially during the last 3 days of pumping. Thus, any wells drilled in the area of the test wells probably would be in no immediate danger of salt-water encroachment; however, a periodic schedule for checking the chloride content of the water would be advisable.

A sample of water for chemical analysis was collected from Eyak Lake on January 23, 1962, to determine whether there was any possibility of chemical contamination of ground water from that source. The chemical quality of the lake water (sample 10) was as good or better than that of the ground water, and recharge from the lake should have no adverse effect upon the quality of water produced by wells near the lake.

All samples collected were well within the accepted standards for drinking water (U.S. Public Health Service, 1962). Ground-water temperatures ranged from $41^{\circ}$ to $42^{\circ} \mathrm{F}$. at the time fieldwork was being done at Cordova, and the variations in temperature at different times of the year would be very slight. During the winter months, water from the existing surface-water supply enters the distribution system at about $32^{\circ} \mathrm{F}$.; use of the slightly warmer ground water would reduce the problem of frozen distribution mains. 


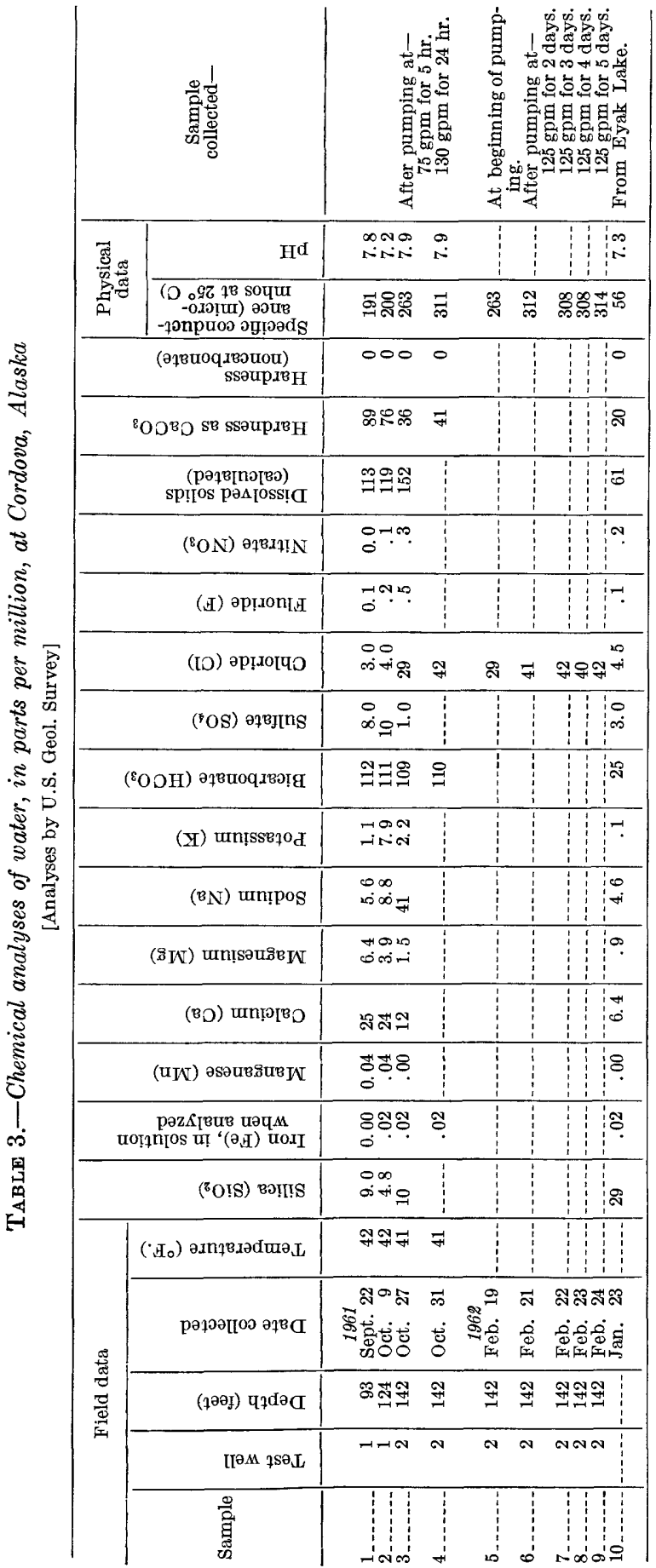




\section{CONCLUSIONS}

The rather low coefficient of transmissibility of materials penetrated by the test wells indicates that ground water is available in rather limited quantities in the Cordova area. A properly constructed well near the site of test well 2 , however, probably would produce enough water to meet the present requirements of the city when surface water from the intake at Merchison Falls is inadequate. However, it would be more practical to construct at least two wells, and pump each of them at a lower rate. The wells should be as far apart as practicable. Surface storage would permit pumping to be discontinuous and take care of peak loads.

Test well 2 did not reach bedrock; hence, more permeable materials than those penetrated may lie at depths greater than 142 feet. A well deeper than test well 2 might produce more water.

The low yield of test well 1 should not eliminate that site as a possible location of a production well. A properly screened well near the site of test well 1 probably would be less productive than a well at the site of test well 2 , but should supply more than the $27 \mathrm{gpm}$ yielded by test well 1 . Test drilling was not done in the area south of test well 2 , and the thickness, yield, and type of unconsolidated materials in this area are unknown. If additional test drilling is done, a site about 600 feet south-southeast of test well 2 should be considered.

All the ground water analyzed in this study was of excellent chemical quality, and moderate pumping probably would cause no harmful deterioration of the quality of water from the zones tested. However, if deeper aquifers are tapped by subsequent drilling, attention should be given to the problem of chloride content of the water in deeper aquifers.

\section{REFERENCES CITED}

Cederstrom, D. J., 1952, Summary of ground-water development in Alaska, 1950: U.S. Geol. Survey Circ. 169, 37 p.

U.S. Public Health Service, 1962, Drinking water standards: Federal Register, Mar. 6, p. 2152-2155. 
